Article

\title{
Deficit Drip Irrigation in Processing Tomato Production in the Mediterranean Basin. A Data Analysis for Italy
}

\author{
Rosa Francaviglia ${ }^{(D)}$ and Claudia Di Bene * \\ Council for Agricultural Research and Economics, Research Centre for Agriculture and \\ Environment (CREA-AA), 00184 Rome, Italy; rosa.francaviglia@crea.gov.it \\ * Correspondence: claudia.dibene@crea.gov.it
}

Received: 8 April 2019; Accepted: 17 April 2019; Published: 19 April 2019

check for updates

\begin{abstract}
In this study, the effects of deficit irrigation (DI) on crop yields and irrigation water utilization efficiency (IWUE) of processing tomato are contrasting. This study aimed at analyzing a set of field experiments with drip irrigation available for Mediterranean Italy in terms of marketable yields and IWUE under DI. Both yields and IWUE were compared with the control treatment under full irrigation, receiving the maximum water restoration (MWR) in each experiment. The study also aimed at testing the effect of climate (aridity index) and soil parameters (texture). Main results indicated that yields would marginally decrease at $70-80 \%$ of MWR and variable irrigation regimes during the crop cycle resulted in higher crop yields. However, results were quite variable and site-dependent. In fact, DI proved more effective in fine textured soils and semiarid climates. We recommend that further research should address variable irrigation regimes and soil and climate conditions that proved more unfavorable in terms of crop response to DI.
\end{abstract}

Keywords: deficit irrigation; Mediterranean region; tomato fruit yield; irrigation water use efficiency

\section{Introduction}

Water resources are extremely scarce in many areas of the world, and water saving has become a priority due to the increase in population and global climate change [1,2]. Agriculture is a major water consumer in regions where irrigation is required for profitable yields, and strategies to reduce water use have the potential to increase sustainability of production. Globally, agricultural irrigation is responsible for $70-80 \%$ of freshwater consumption $[3,4]$. Increased water savings and optimization of irrigation management as much as possible are, thus, urgently needed. A small amount of water saved can be used for other purposes. Therefore, in recent decades, agricultural water use efficiency has been improved by innovations in technology and plant breeding. Irrigation systems and scheduling mainly affect crop yields. Thus, the knowledge of crop water requirement, the reference crop evapotranspiration, and the rainfall of the target region is recommended [5]. While full irrigation (FI) aims to meet crop water requirements to maximize crop yield, in deficit irrigation (DI) water use is optimized in relation to crop yield per volume of water consumed. Modest yield reductions can be acceptable if connected to a significant reduction in water use [6]. DI has been found suitable for grapevine and fruit crops, but vegetables might suffer from losses in yield and quality. DI effects on crop yield and water efficiency have been studied on several crops, including tomato (Solanum lycopersicum L.), though with contrasting results that can be ascribed to the different cultivars cultivated or the period of DI application during the crop cycle [6]. Although farm income is higher with increasing yields when more water is supplied with irrigation, water availability is continuously decreasing due to the competing requirements of agriculture, industry, recreation, and the environment. In addition, DI 
provides an effective adaptive response to water scarcity within a climate change perspective [7], and lower yields might be compensated by the increased production and farm income from additional lands irrigated with the water saved by DI $[8,9]$.

Most of horticultural production areas are in hot and dry climates due to favorable weather conditions (high light, high temperature), as in Mediterranean regions, however, soil water deficit is rather frequent. Tomato is considered one of the most commonly consumed vegetables and economically important crops in the world, and has the highest planted areas of all vegetables worldwide. It is characterized by high-water needs [10] due to the high temperatures and the large gap between rainfall and evapotranspiration (ET) during the long spring-summer growing season [2]. Tomato is a drought sensitive plant because its yield decreases considerably after short periods of water deficiency [5]. The application of DI strategies during tomato growing season may greatly contribute to saving irrigation water [11,12] without affecting tomato yield, compared with (FI) receiving the maximum water restoration (MWR), at a rate of $100 \%$ ET [13]. Nevertheless, water deficits at different growth stages can differentially affect tomato yield. Results of crop simulation models showed that certain tomato life stages, such as the flowering and fruiting stages, were more susceptible to water stress than the seedling stage [14].

According to the World Processing Tomato Council [15] (an international non-profit organization representing the tomato processing industry), Italy is ranked as the second producer of processing tomato worldwide, after California and followed by China. Italy is the leading country in Europe, contributing to $44 \%$ of the total amount, followed by Spain (27\%), Turkey (12\%) and Portugal (11\%). The total national production in 2018 was 4,811,955 t, cultivated on a surface of 72,504 ha (average marketable yield is $66 \mathrm{t} \mathrm{ha}^{-1}$ ). The two most important production regions are Emilia-Romagna in the north and Apulia in the south (concentrated in the Capitanata plain, in Foggia province). The two regions contributed in 2018 to 35 and 32\% respectively of the national production of processing tomato, as reported by official statistics [16]. Average yields were 69 and $85 \mathrm{t} \mathrm{ha}^{-1}$, respectively. In these areas processing tomato cultivation is highly intensive due to large and regular application of irrigation water and nutrient inputs during flowering and fruit formation $[17,18]$, which may create the potential for negative side-effects on the environment [19]. Thus, the application of water saving strategies is of particular interest where water availability is limited and to save water while maximizing tomato yields under water deficit conditions [20,21]. Since the price of water is increasing, DI is an effective strategy to provide an adequate economic profit for farmers in Mediterranean environments [22]. Moreover, results of crop simulation models in southern Italy have shown that climate change would decrease tomato yields due to the shorter crop cycle induced by the temperature increase $[23,24]$. Besides water savings, gains in fruit quality (higher soluble solid contents and fruit color intensity) can often compensate for the losses in fruit yields [11,21]. However, the contrasting results available in the scientific literature suggest the need to better understand site-dependent plant responses to water deficit with DI $[25,26]$.

A quantitative analysis is important to provide suggestions for improving crop yield and recommendations of irrigation water inputs in processing tomato cultivation under Mediterranean conditions. The present study is aimed at evaluating the effect of DI irrigation on processing tomato in field experiments derived from a literature search. Data were analyzed in terms of marketable yields, water restoration, and irrigation water use efficiency (IWUE) under DI compared with the control treatment under full irrigation, receiving the MWR in each experiment. The study also aimed at testing the effect of climate (aridity index) and soil parameters (texture).

\section{Materials and Methods}

\subsection{Data Collection and Case Studies}

To assess the effect of deficit drip irrigation on tomato yields, a data search of existing field studies was performed. The literature search was performed with SCOPUS with no source limitations (all 
years, article types, and access types). Literature was screened by searching three fields in the title, abstract, and keywords of the source reference: "Mediterranean" AND "Italy" AND "tomato". Results referring to greenhouse studies, pot experiments, Life Cycle Assessment, and simulation studies addressing crop development and water dynamics were excluded from the data analysis.

Information derived from field experiments included: region, province, altitude ( $\mathrm{m}$ above sea level), long-term mean annual temperature $\left(\mathrm{MAT}^{\circ} \mathrm{C}\right.$ ) and total rainfall (MAP $\mathrm{mm}$ ), aridity index, rainfall and irrigation during the growth cycle, marketable yield as fresh and dry matter, irrigation treatments, and soil texture group (Table S1). Crop evapotranspiration (ETc) in the different field experiments was estimated by the authors as the product of reference evapotranspiration (ETo), calculated with the FAO Penman-Monteith equation [27] or using Class A pan evaporation and Kpan [28], and tomato-specific crop coefficient $(\mathrm{Kc})$. All experiments preformed were under drip irrigation.

Using these criteria 10 studies, totaling 54 yield observations, were found in four regions of Italy: Apulia (3), Basilicata (3), Latium (2), and Sicily (2).

\subsubsection{Apulia}

A two-year field research (2011-2012) was carried out at Valenzano $\left(41^{\circ} 03^{\prime} \mathrm{N}, 16^{\circ} 52^{\prime} \mathrm{E}\right.$, altitude $72 \mathrm{~m}$ a.s.l) in Bari Province [29]. MAT and MAP were $16.2^{\circ} \mathrm{C}$ and $523 \mathrm{~mm}$, respectively. Tomato (cv. Tomato F1) was grown under three irrigation regimes: full recover of crop evapotranspiration (I100), 50\% of full irrigation supply (I50), and rainfed (I0). Tomato was transplanted in mid-April, and fertilized with 100, 120, and $150 \mathrm{~kg} \mathrm{ha}^{-1}$ of $\mathrm{N}, \mathrm{P}_{2} \mathrm{O}_{5}$, and $\mathrm{K}_{2} \mathrm{O}$, respectively.

A field research was carried out in 2011 in Foggia province $\left(41^{\circ} 45^{\prime} \mathrm{N}, 15^{\circ} 50^{\prime} \mathrm{E}\right.$, altitude $90 \mathrm{~m}$ a.s.l), with MAT and MAP of $15.8^{\circ} \mathrm{C}$ and $526 \mathrm{~mm}$, respectively [22]. Four irrigation regimes re-establishing 125\% (ET125), 100\% (ET100), 75\% (ET75), and 50\% (ET50) of ETc were considered. Tomato (cv. Defender F1) was transplanted in mid-May and fertilized with 133,75 , and $90 \mathrm{~kg} \mathrm{ha}^{-1}$, respectively, of $\mathrm{N}_{2} \mathrm{P}_{2} \mathrm{O}_{5}$, and $\mathrm{K}_{2} \mathrm{O}$.

A two-year experiment (2009-2010) was carried out in Foggia province $\left(41^{\circ} 24^{\prime} \mathrm{N}, 15^{\circ} 45^{\prime} \mathrm{E}\right.$., altitude $30 \mathrm{~m}$ a.s.l) with MAT and MAP of $15.8^{\circ} \mathrm{C}$ and $526 \mathrm{~mm}$ respectively [30]. Tomato was cultivated under four irrigation regimes: DI, constant regime with restoration of $60 \%$ of maximum ETc during the crop cycle; RDI, variable irrigation regime with $60 \%, 80 \%$, and $60 \%$ of maximum ETc through the three main phenological stages of the crop cycle; FI, full irrigation regime with the restoration of $100 \%$ ETc; FaI, farmer irrigation regime based on usual farming routine. Tomato (cv. Genius F1) was transplanted in the first decade of May and fertilized with 154 and $56 \mathrm{~kg} \mathrm{ha}^{-1}$ of $\mathrm{N}$ and $\mathrm{P}_{2} \mathrm{O}_{5}$, respectively.

\subsubsection{Basilicata}

A two-year experiment (2002-2003) was carried out in Lavello $\left(41^{\circ} 03^{\prime} \mathrm{N}, 15^{\circ} 42^{\prime} \mathrm{E}\right.$, altitude $180 \mathrm{~m}$ a.s.l) in Potenza province [31]. MAT and MAP were $14.5^{\circ} \mathrm{C}$ and $518 \mathrm{~mm}$, respectively. Tomato was cultivated under six irrigation regimes: (i) four constant irrigation regimes with restoration of 0 (T0), 50 (T1), 75 (T2), and 100\% (T3) of ETc during the whole crop cycle; (ii) two variable irrigation regimes with $100 \%$ restoration of ETc during the first period of the crop growth, followed by 75 or $50 \%$ restoration of ETc in the second part of the cycle (T4 and T5 treatments respectively). Tomato (cv. Pullrex) was transplanted after mid-May, and fertilized with 182,214 , and $160 \mathrm{~kg} \mathrm{ha}^{-1}$ of $\mathrm{N}_{1} \mathrm{P}_{2} \mathrm{O}_{5}$, and $\mathrm{K}_{2} \mathrm{O}$, respectively.

A first field experiment carried out at Metaponto $\left(40^{\circ} 24^{\prime} \mathrm{N}, 16^{\circ} 48^{\prime} \mathrm{E}\right.$, altitude $10 \mathrm{~m}$ a.s.l) in Matera province [32] reported the results related to 2007 and 2009 growing cycles. MAT and MAP were $16.5^{\circ} \mathrm{C}$ and $493 \mathrm{~mm}$, respectively. Three irrigation treatments were compared: re-establishing 50 (I1), 75 (I2), and $100 \%$ (I3) of the crop evapotranspiration (ETc). Tomato (cv Tomito) was transplanted in mid-May and fertilized with $180 \mathrm{~kg} \mathrm{ha}^{-1}$ of $\mathrm{N}$.

A second two-year experiment (2008-2009) in the same area compared three irrigation regimes: V100, full restoration (100\%) of ETc, V50, 50\% restoration of ETc, and V0, no water restoration [33]. Tomato (cv. Faino F1) was transplanted in late May and fertilized with $160 \mathrm{~kg} \mathrm{ha}^{-1}$ of N. 


\subsubsection{Latium}

Two field experiments were carried out in Viterbo province $\left(42^{\circ} 43^{\prime} \mathrm{N}, 12^{\circ} 07^{\prime} \mathrm{E}\right.$, altitude $310 \mathrm{~m}$ a.s.l). MAT and MAP were $14.4^{\circ} \mathrm{C}$ and $746 \mathrm{~mm}$ respectively. The first research [34] was conducted in 1997, and compared four irrigation regimes: $50-75,50-100,75-50$, and $100-75 \%$ restitution of ETc in the first (from planting to fruit set) and in the second (from fruit set to harvest) growth period. Tomato (hybrid PS 1296) was transplanted at the end of May with three fertilization treatments: control (no fertilization), D1 with 79,68 , and $107 \mathrm{~kg} \mathrm{ha}^{-1}$ of $\mathrm{N}, \mathrm{P}_{2} \mathrm{O}_{5}$, and $\mathrm{K}_{2} \mathrm{O}$ respectively, and D2 (double the doses of D1).

The second experiment [35] was carried out in 2006-2007 and compared two irrigation treatments: full irrigation (FULL) restoring $100 \%$ of ETc, and deficit irrigation (DI), restoring $50 \%$ of ETc. Tomato (cv. Carioca). which were transplanted in mid-May and fertilized with 152, 200, and $150 \mathrm{~kg} \mathrm{ha}^{-1}$ of N, $\mathrm{P}_{2} \mathrm{O}_{5}$, and $\mathrm{K}_{2} \mathrm{O}$, respectively.

\subsubsection{Sicily}

A two-year field experiment [12] was carried out in 2001-2002 in Enna province ( $37^{\circ} 27^{\prime} \mathrm{N}, 14^{\circ} 14^{\prime} \mathrm{E}$, altitude $550 \mathrm{~m}$ a.s.1.). MAT and MAP were $15.4^{\circ} \mathrm{C}$ and $514 \mathrm{~mm}$ respectively. Four irrigation treatments were compared: no irrigation after plant establishment (V0), 100\% (V100) or 50\% (V50) ETc restoration up to fruit maturity, $100 \%$ ETc restoration up to flowering, then $50 \%$ ETc restoration (V100-50). Tomato (cv. Brigade) was transplanted in early May and fertilized with 150, 229, and $120 \mathrm{~kg} \mathrm{ha}^{-1}$ of $\mathrm{N}_{2} \mathrm{P}_{2} \mathrm{O}_{5}$, and $\mathrm{K}_{2} \mathrm{O}$, respectively.

A field experiment [26] was conducted in 2002 in Siracusa province $\left(37^{\circ} 03^{\prime} \mathrm{N}, 15^{\circ} 18^{\prime} \mathrm{E}\right.$, altitude $10 \mathrm{~m}$ a.s.l.). MAT and MAP were $17.8^{\circ} \mathrm{C}$ and $504 \mathrm{~mm}$, respectively. Five irrigation regimes were compared: no irrigation after plant establishment (NI), long-season full irrigation with $100 \%$ ETc restoration (LF), long-season deficit irrigation with 50\% ETc restoration (LD), short-season full irrigation up to first fruit set with $100 \%$ ETc restoration (SF), and short-season deficit irrigation up to first fruit set with 50\% ETc restoration (SD). Tomato (cv. Brigade) was transplanted in early May and fertilized with 150,229 , and $120 \mathrm{~kg} \mathrm{ha}^{-1}$ of $\mathrm{N}, \mathrm{P}_{2} \mathrm{O}_{5}$, and $\mathrm{K}_{2} \mathrm{O}$ respectively.

\subsection{Data Evaluation}

Marketable fruit yields ( $\mathrm{Mg} \mathrm{ha}^{-1}$ fresh weight) under deficit irrigation (DI) were compared with yields of the control treatment with the maximum water restoration (MWR) of each experiment, including rainfall:

$$
\text { Yield }(\%)=\text { Yield }_{\mathrm{DI}} / \text { Yield }_{\mathrm{MWR}} \times 100
$$

Irrigation water use efficiency (IWUE) of the different treatments was calculated according to [36]:

$$
\text { IWUE }=\text { Yield/TWS }
$$

where Yield is the fruit dry biomass at harvest $\left(\mathrm{kg} \mathrm{ha}^{-1}\right)$, and TWS is the total water supply including irrigation and rainfall from planting to harvest $\left(\mathrm{m}^{3} \mathrm{ha}^{-1}\right)$.

The Aridity index [37] was calculated with the formula Aridity index $=\mathrm{MAP} /(\mathrm{MAT}+10)$ that defines aridity classes as humid (30-60), sub-humid (20-30), semi-arid (15-20), arid (5-15), and strongly-arid $(<5)$. Total water supplies with deficit irrigation during the crop cycle were divided in five classes based on the \% of maximum water restoration (MWR): 0-20, 20-40, 40-60, 60-80, and $80-100 \%$. Soil texture group was evaluated according to Soil Taxonomy [38] as (C) coarse (sandy loam, sandy clay loam, loamy sand), (M) medium (clay loam, loam, silty clay loam, silt, silt loam), and (F) fine (clay, silt clay, sandy clay).

Statistical analyses were performed using Statistica 7.0 (Statsoft, Tulsa, OK, USA). Significant differences among means were evaluated through the Fisher's protected least significant difference test (LSD post hoc test). 


\section{Results}

A summary of maximum marketable fruit yields $\left(\mathrm{Mg}\right.$ fresh weight ha $\left.{ }^{-1}\right)$ under full irrigation and the related total water supply $(\mathrm{mm})$ by rainfall and irrigation during the crop cycle in the different provinces are shown in Figures 1 and 2. Marketable yields ranged from 114.2 to $51.0 \mathrm{Mg} \mathrm{ha}^{-1}$, respectively, at Matera and Siracusa. Total water supplies ranged from 768 to $395 \mathrm{~mm}$ at Foggia and Enna, respectively. The result for Matera, coupling a high marketable fruit yield (114.2 $\left.\mathrm{Mg} \mathrm{ha}^{-1}\right)$ and a low water supply $(517 \mathrm{~mm})$, are an indication of a proper irrigation schedule when fully restoring crop evapotranspiration. Conversely, at Foggia a slightly lower marketable fruit yield $\left(95.2 \mathrm{Mg} \mathrm{ha}^{-1}\right.$ ) was coupled with a higher water supply $(768 \mathrm{~mm})$, indicating the ineffectiveness in productive terms of water supplies following the farmer routine, using more water than the full irrigation regime, restoring $100 \%$ of ETc [30].

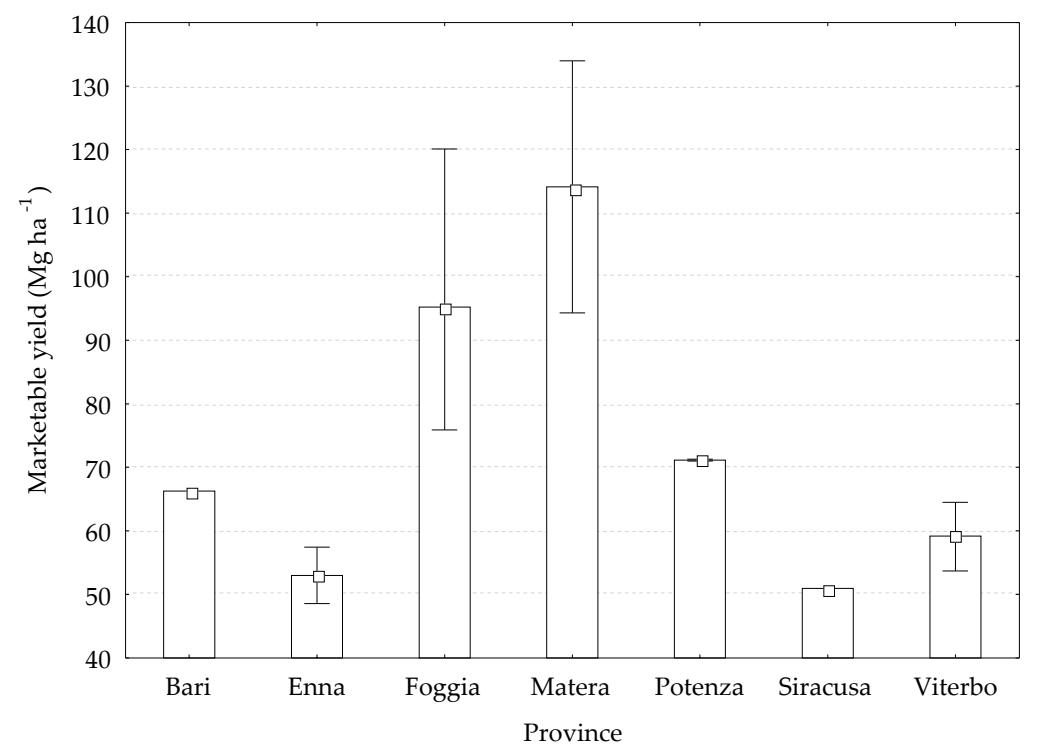

Figure 1. Maximum marketable fruit yield $\left(\mathrm{Mg}\right.$ fresh weight ha $\left.{ }^{-1}\right)$ in the different provinces under full irrigation. Boxes represent mean values, whiskers represent Min-Max interval.

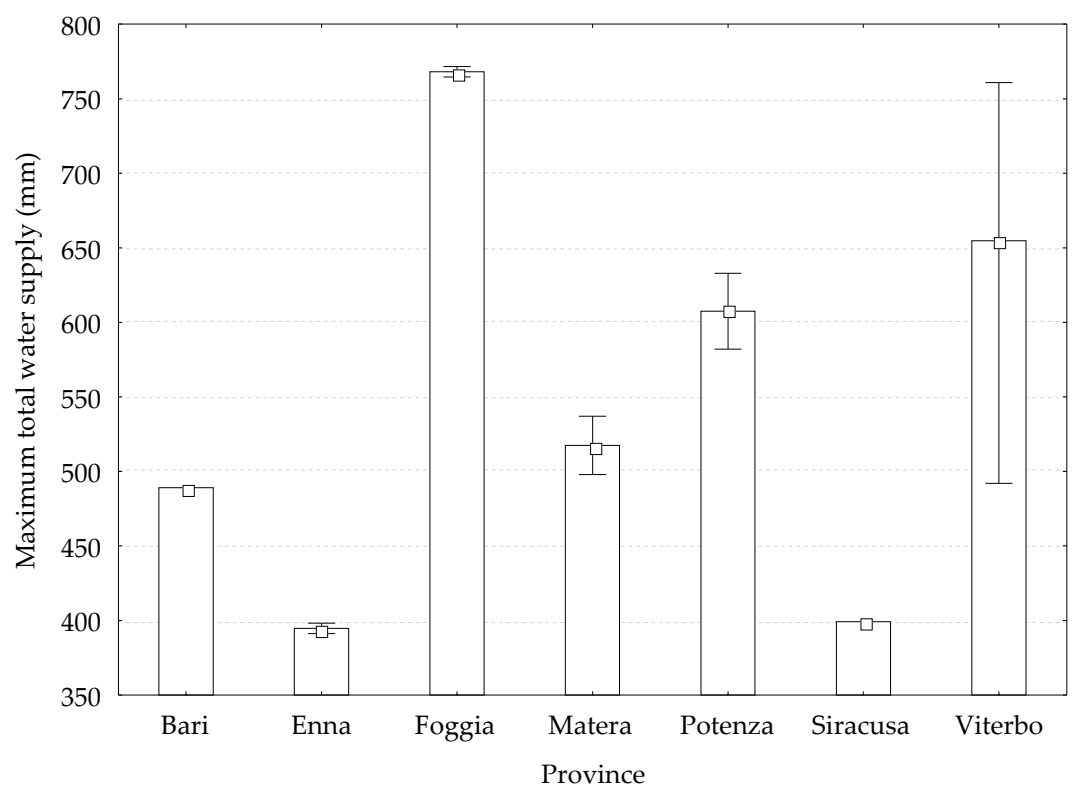

Figure 2. Total water supply $(\mathrm{mm})$ under full irrigation in the different provinces. Boxes represent mean values, whiskers represent Min-Max interval. 


\subsection{Marketable Yield and Water Restoration}

When comparing marketable fruit yields under DI with the control treatment (Equation (1)), average yields $(\%)$ significantly differed among irrigation classes $(p=0.0000)$. In detail (Figure 3$)$, yields were significantly lower in 0-20 and 20-40 irrigation classes ( 31.5 and $27.3 \%$ respectively) and higher in 40-60, 60-80, and 80-100 classes (74.9, 72.6, and 87.4\% respectively).

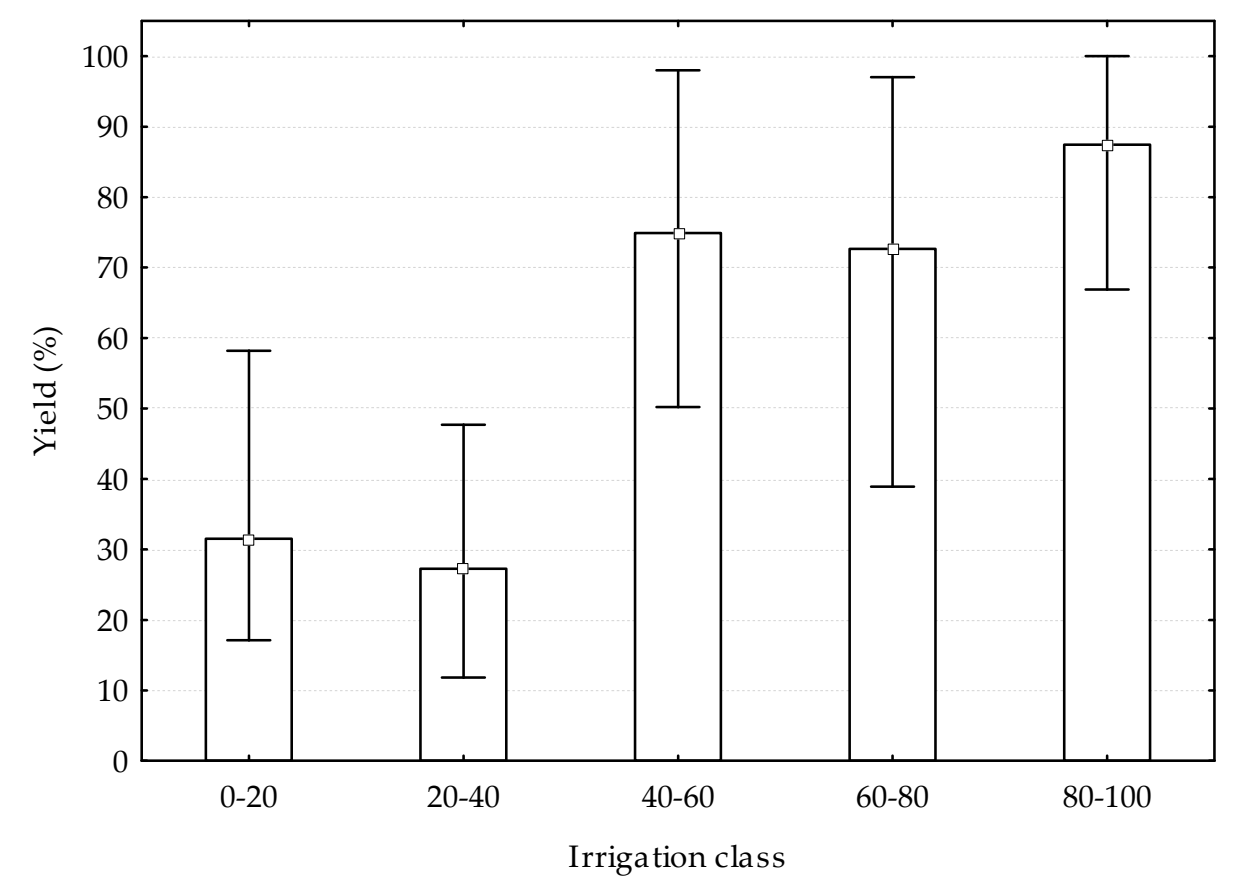

Figure 3. Tomato fresh fruit yield (\%) compared with the control treatment based on the irrigation classes as $\%$ of maximum water restoration (MWR), $\mathrm{F}(4 ; 35)=14.1531 ; p=0.00000$. Boxes represent mean values, whiskers Min-Max interval.

Average yields (\%) significantly differed among irrigation regimes $(p=0.0000)$. As expected, yields (Figure 4) were significantly lower with none irrigation excluding rainfall during the crop cycle $(26.8 \%)$, and did not differ between constant and variable regimes with the regulated deficit irrigation (RDI) but were lower under constant irrigation (74.0\%) in comparison with RDI (85.7\%). 


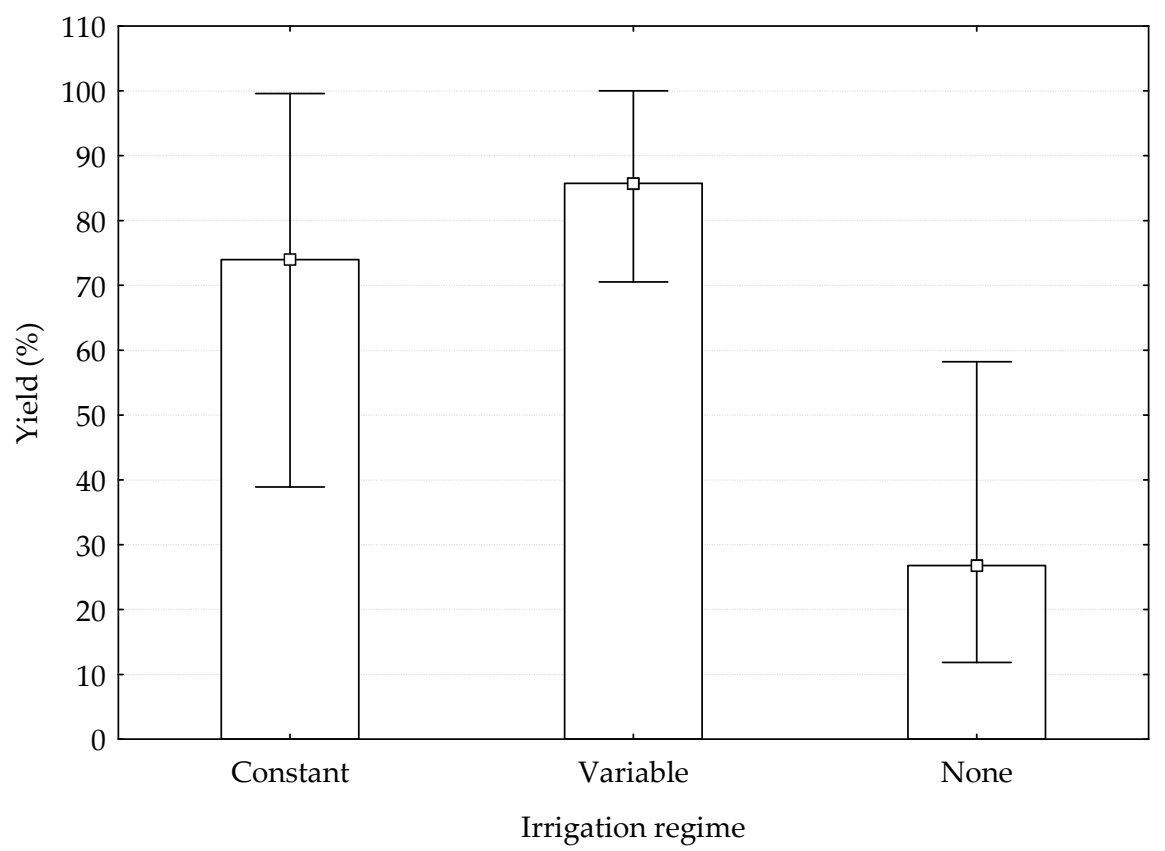

Figure 4. Tomato fresh fruit yield (\%) based on the irrigation regimes, $\mathrm{F}(2 ; 37)=25.6319 ; p=0.00000$. Boxes represent mean values, whiskers represent Min-Max interval.

Fresh fruit yield (\%) and maximum water restoration (\%) supplied with DI were interpolated (Figure 5) with a polynomial equation: $y=-0.0039 x^{2}+1.2053 x+16.8326\left(R^{2}=0.7045\right)$. The interpolating function indicated that yields would decrease by $6.3,8.9$, and $11.7 \%$ at 90,85 , and $80 \%$ of maximum water restoration (MWR), but would still be acceptable at 75 and $70 \%$ of MWR with decreases of 14.7 and $17.9 \%$.

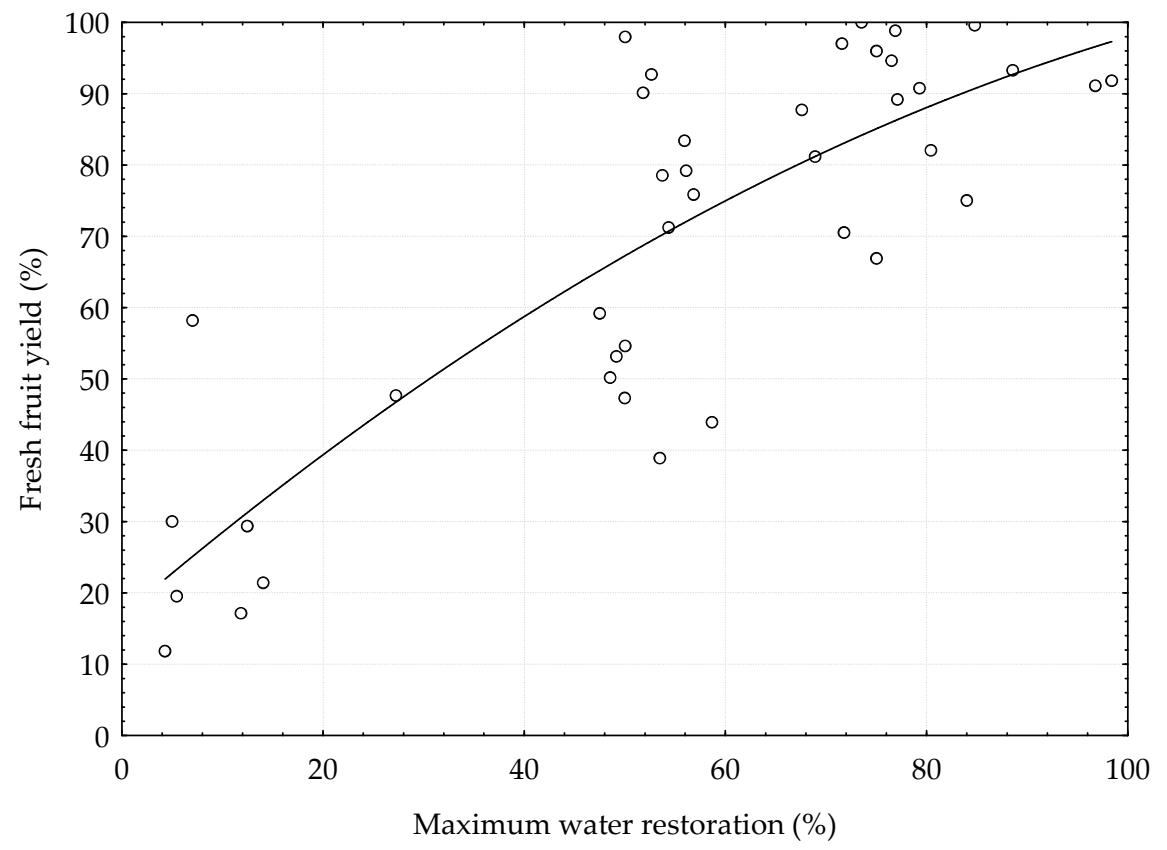

Figure 5. Tomato fresh fruit yield (\%) as a function of maximum water restoration (\%).

Marketable fruit yields ( $\mathrm{Mg}$ fresh weight $\mathrm{ha}^{-1}$ ) under DI significantly differed among the provinces $(p=0.00006)$ where the field experiments were conducted (Figure 6). Average yields were significantly lower at Bari, Siracusa, Enna, Viterbo, and Potenza (22.2, 27.4, 36.0, 41.1, and 50.3 $\mathrm{Mg} \mathrm{ha}^{-1}$, respectively) 
compared to Foggia and Matera (75.4 and $92.7 \mathrm{Mg} \mathrm{ha}^{-1}$, respectively). Compared with marketable yields under full irrigation (Figure 1), decreases were as follows: Bari (67\%), Siracusa (46\%), Enna $(32 \%)$, Viterbo (31\%), Potenza (29\%), Foggia (21\%), and Matera (19\%).

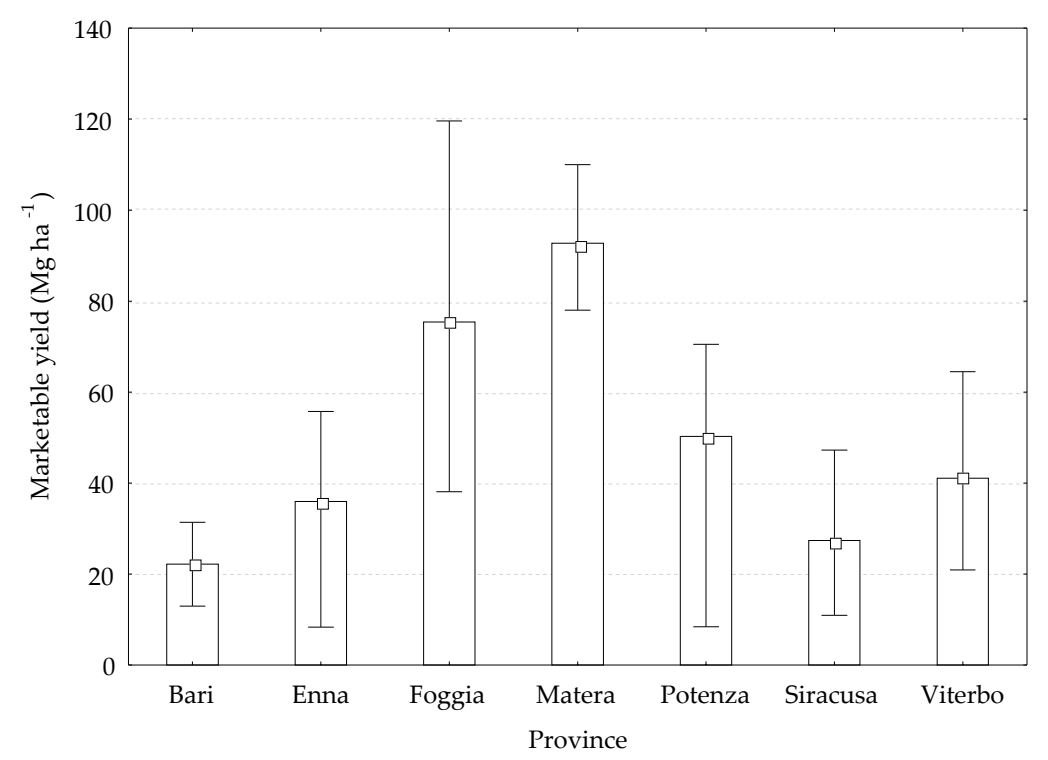

Figure 6. Marketable yield ( $\mathrm{Mg}$ fresh weight $\mathrm{ha}^{-1}$ ) in the different provinces under DI, F (6;33) = 7.1298; $p=0.00006$. Boxes represent mean values, whiskers represent Min-Max interval.

Marketable fruit yields (Mg fresh weight $\mathrm{ha}^{-1}$ ) under DI also significantly differed among soil texture groups ( $p=0.0049$ ) and average yields (Figure 7) were significantly lower in field experiments with coarse and medium texture ( 32.5 and $51.7 \mathrm{Mg}$ fresh weight ha ${ }^{-1}$, respectively) compared to fine textured soils (75.4 Mg fresh weight ha ${ }^{-1}$ ). This result is coherent with the soil textures of the field experiments, which were fine and medium at Foggia and Matera, respectively, and also showed the lowest yield decreases; conversely, at Bari soils were coarse textured and presented the highest yield decrease under DI (Figure 6).

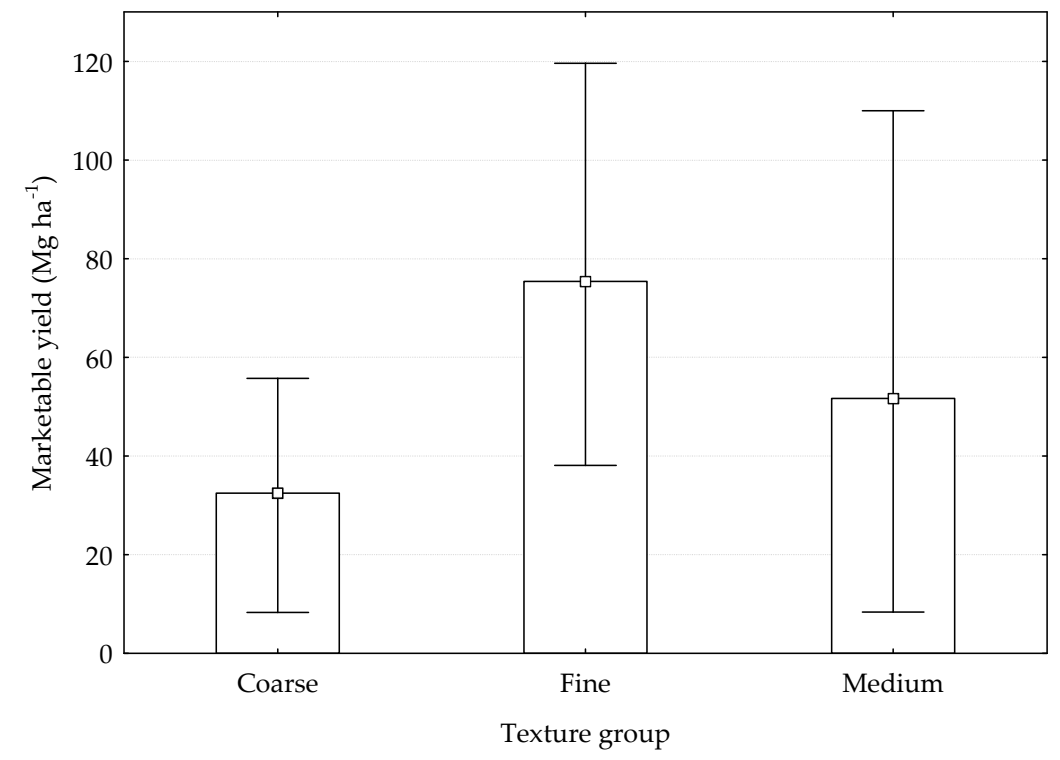

Figure 7. Marketable yield ( $\mathrm{Mg}$ fresh weight $\left.\mathrm{ha}^{-1}\right)$ under DI based on soil texture groups according to United States Department of Agriculture (USDA), F $(2 ; 37)=6.1615 ; p=0.0049$. Boxes represent mean values, whiskers represent Min-Max interval. 


\subsection{Irrigation Water Use Efficiency and Water Restoration}

Irrigation water use efficiency (IWUE in $\mathrm{kg}$ dry weight $\mathrm{m}^{-3}$ ) was weakly significantly different $(p=0.0683$ ) among irrigation classes (Figure 8). Average IWUE was significantly higher only in 0-20 irrigation class $\left(1.67 \mathrm{~kg} \mathrm{~m}^{-3}\right)$ compared to the other classes.

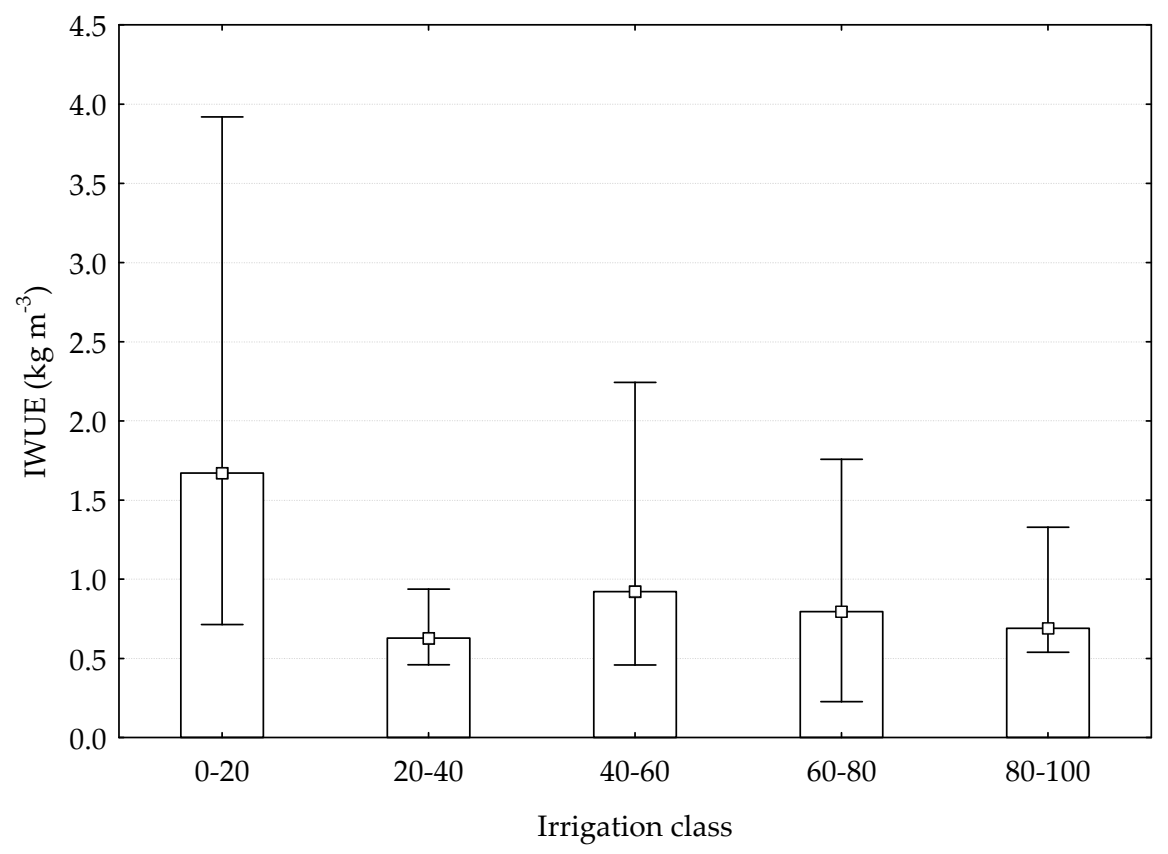

Figure 8. Irrigation Water Use Efficiency (IWUE) $\left(\mathrm{kg}\right.$ dry weight $\left.\mathrm{m}^{-3}\right)$ based on the irrigation classes as $\%$ of maximum water restoration (MWR), $\mathrm{F}(4 ; 35)=2.403 ; p=0.0683$. Boxes represent mean values, whiskers represent Min-Max interval.

In relation to irrigation regimes (Figure 9), IWUE was not significantly different $(p=0.2366)$. IWUE was higher with no irrigation $\left(1.18 \mathrm{~kg} \mathrm{~m}^{-3}\right)$ and decreased with constant and variable irrigation regimes (0.86 and $0.66 \mathrm{~kg} \mathrm{~m}^{-3}$, respectively).

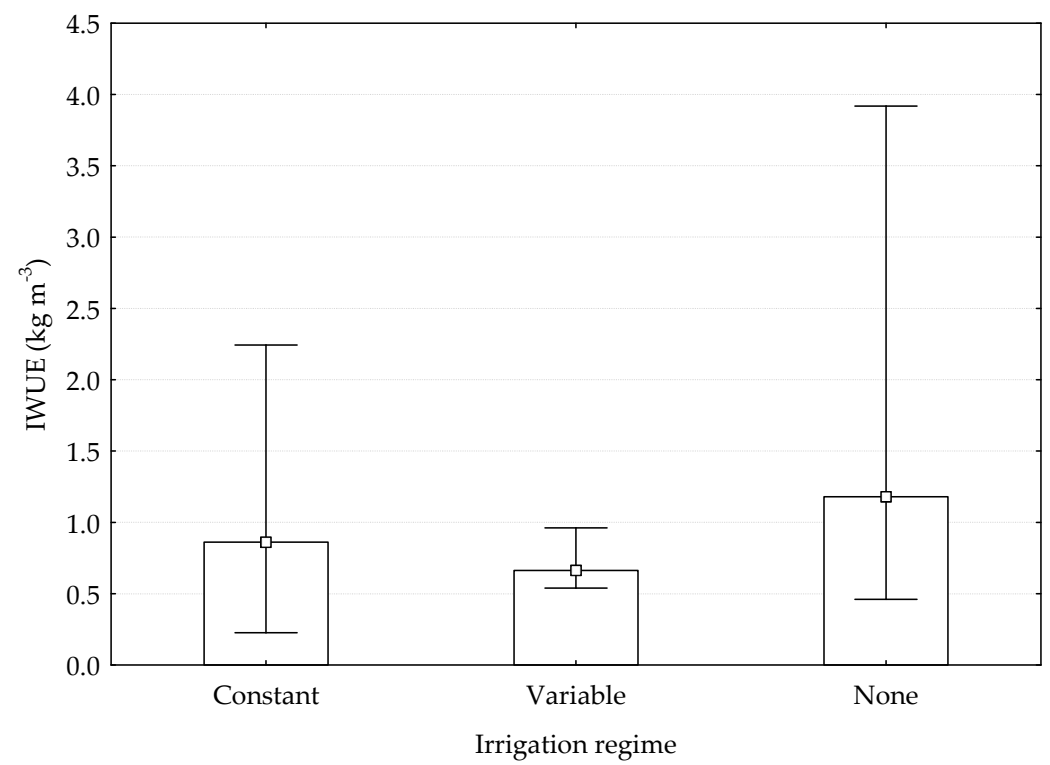

Figure 9. Irrigation Water Use Efficiency (IWUE) $\left(\mathrm{kg}\right.$ dry weight $\left.\mathrm{m}^{-3}\right)$ based on irrigation regimes, $\mathrm{F}$ $(2 ; 37)=1.4992 ; p=0.2366$. Boxes represent mean values, whiskers represent Min-Max interval. 
IWUE significantly differed among the provinces $(p=0.0000)$ where the field experiments were conducted (Figure 10). In detail, average IWUE was significantly lower at Viterbo, Bari, Potenza, Foggia Siracusa, and Enna (0.47, 0.49, 0.61, 0.75, 0.80, and $0.98 \mathrm{~kg} \mathrm{~m}^{-3}$, respectively) compared to Matera $\left(2.31 \mathrm{~kg} \mathrm{~m}^{-3}\right)$. Results for Matera are in agreement with the low decreases observed in marketable yields.

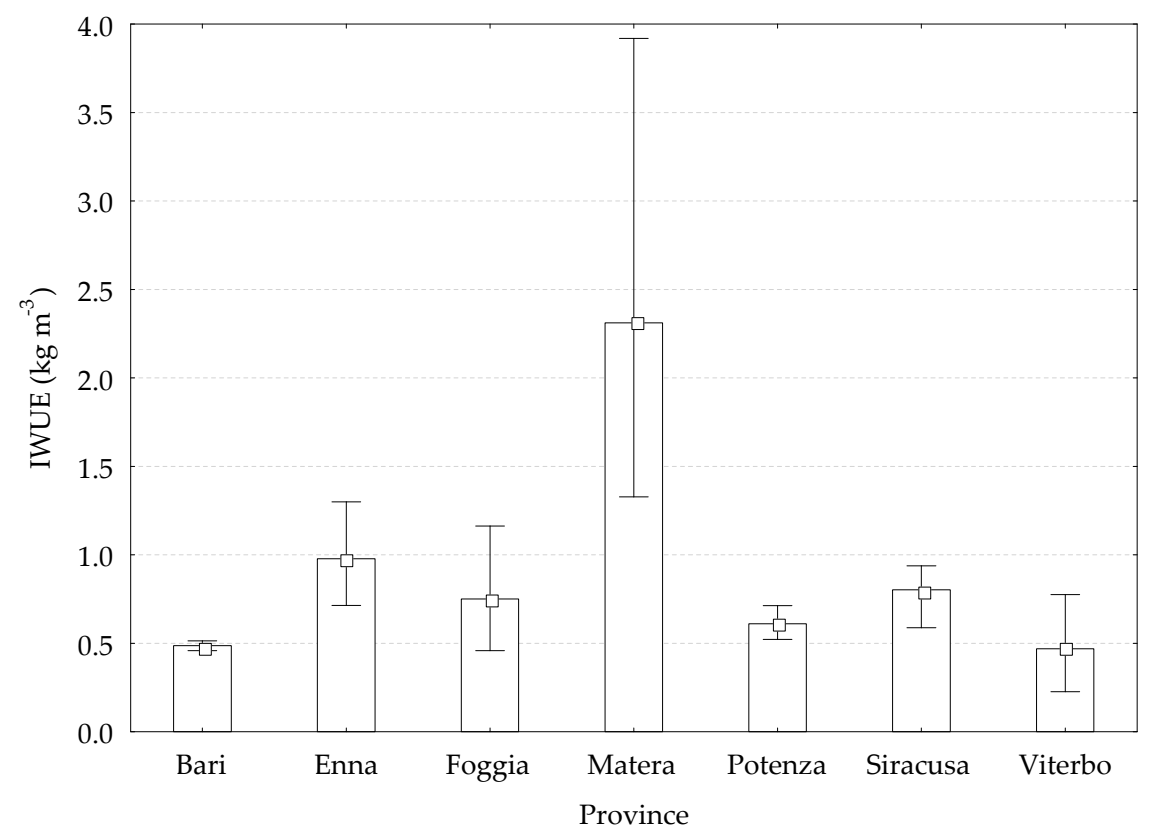

Figure 10. Irrigation Water Use Efficiency (IWUE) $\left(\mathrm{kg}\right.$ dry weight $\left.\mathrm{m}^{-3}\right)$ in the different provinces, $\mathrm{F}$ $(6 ; 33)=11.5912 ; p=0.0000$. Boxes represent mean values, whiskers represent Min-Max interval.

IWUE also significantly differed among aridity classes $(p=0.0092)$ and on average was significantly lower (Figure 11) in field experiments under humid and sub-humid climates $\left(0.47\right.$ and $0.75 \mathrm{~kg} \mathrm{~m}^{-3}$, respectively) compared to semiarid conditions $\left(1.34 \mathrm{~kg} \mathrm{~m}^{-3}\right)$. Considering the location of field experiments, humid climate conditions are related to Viterbo in Latium, and semiarid conditions to Matera in Basilicata.

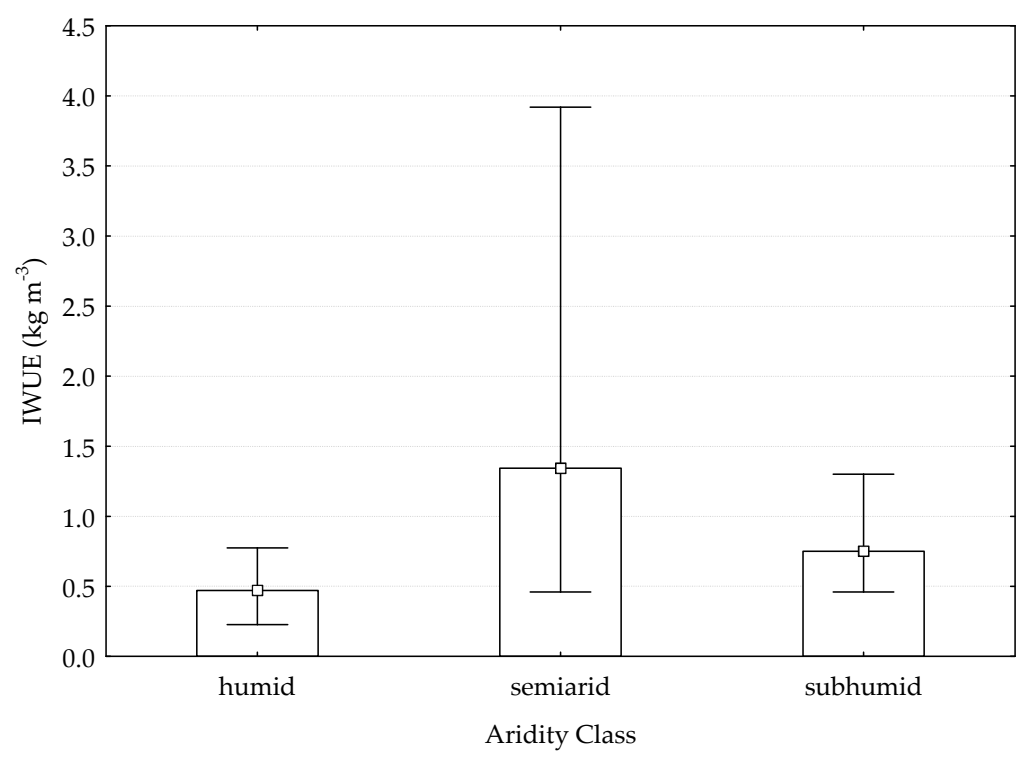

Figure 11. Irrigation Water Use Efficiency (IWUE) $\left(\mathrm{kg}\right.$ dry weight $\left.\mathrm{m}^{-3}\right)$ based on the aridity classes [37], $\mathrm{F}(2 ; 37)=5.3391 ; p=0.0092$. Boxes represent mean values, whiskers represent Min-Max interval. 


\section{Discussion}

In the environments typical of the Mediterranean area the use of water resources for irrigation is a priority to be managed through sustainable regulation of water supplies, contributing to water savings with environmental and economic benefits [39] but avoiding high productivity losses to maintain profit for farmers [6,30]. Research also indicated that DI may have positive side effects, such as contributing to decreased soil $\mathrm{CO}_{2}$ emissions and enhanced $\mathrm{C}$ sequestration in soils, by decreasing microbial activity in response to decreased soil moisture levels [39]. In addition, nitrogen fertilization also results in lower $\mathrm{N}_{2} \mathrm{O}$ emissions in Mediterranean regions with drip irrigation systems that are commonly used in tomato cultivation compared with sprinkler irrigation methods [40].

Results from the different field experiments examined in this study are in contrast with each other. Data obtained in a study at Foggia in Apulia [30] indicated that farmers tend to over irrigate tomato crops, with no significant increase in the marketable fruit yield and quality, as reported in other research [20]. Moreover, the same authors [30] indicated that the adoption of variable irrigation regimes as RDI restoration of $60 \%, 80 \%$, and $60 \%$ of the maximum ETc during the three main tomato phenological stages (i.e., from plant establishment to flowering of the first truss, from flowering of the first truss to fruit breaking colors of the first truss, and from fruit breaking colors of the first truss to harvest), was effective to save water, as shown by other authors [31,34] at Viterbo (Latium) and Lavello (Basilicata). A study at Matera in Basilicata [32] indicated that water restoration of 50, 75, and $100 \%$ of crop evapotranspiration showed no statistical differences among the irrigation volumes in relation to tomato yield and quality. Conversely, in the same environment another study [33] reported statistically significant differences in both marketable yields and fruit quality when restoring 0,50 , and $100 \%$ of ETc.

The study conducted at Enna in Sicily [12] showed that marketable yields were strongly decreased by early soil water deficit following plant establishment, while a reduced irrigation rate after the initial stages or after flowering did not induce any significant loss. The study also indicated that DI has beneficial effects on fruit quality. In particular, a high total solids content of the fruit improves the efficiency of the industrial process due to the lower energy required to evaporate water from fruit. Tomato yield also proved more sensitive to the length of the irrigation period rather than to the total water supplied during DI experiments in Sicily [26]. In fact, the long-season deficit irrigation (LD) with $50 \%$ ETc restoration and the short-season full irrigation (SF) with $100 \%$ ETc restoration received about the same amount of water, but yields decreased by $46 \%$ in SF. In addition, irrigation cut-off during the ripening period did not significantly affect marketable yields and enhanced fruit quality [31].

In the case of Foggia and Viterbo, the average irrigation supplied (Figure 2) was the highest (768 and $655 \mathrm{~mm}$, respectively). However, marketable yields with full irrigation (Figure 1) were higher in Foggia than in Viterbo ( 95 and $59 \mathrm{Mg}$ fresh weight $\mathrm{ha}^{-1}$ ). This result can be ascribed firstly to the lower fertilization supplied at Viterbo (average $\mathrm{N}$ fertilization was about two thirds compared to the amount supplied at Foggia), and secondly to other environmental conditions that can positively or negatively affect crop yields (e.g., air temperature). In fact, average temperature is $15.8^{\circ} \mathrm{C}$ at Foggia and climate is sub-humid; at Viterbo temperature is $14.4^{\circ} \mathrm{C}$ and climate is humid. The same consideration is valid in relation to IWUE. In fact, average IWUE was higher at Matera (Figure 10), where temperature is $16.5^{\circ} \mathrm{C}$ and climate is semi-arid (Figure 11 ).

Generally, our data-analysis has confirmed that results are quite variable and strongly site-dependent due to different climate and soil conditions that may mask the actual effect of the irrigation regime, and consequently cannot be generalized. Based on the field experiments considered, a limited decrease in water restoration according to the calculated interpolating function (Figure 5) would marginally decrease yield by $17.9 \%$ and $11.7 \%$, at 70 and $80 \%$ of maximum water restoration, respectively. Marketable yields did not differ significantly at $40-60 \%$ and $60-80 \%$ of maximum water restoration (Figure 3) but were higher when $80-100 \%$ of maximum water restoration was supplied with DI, in agreement with previous research [20]. In addition, variable irrigation regimes during the crop cycle showed a higher and significant response to crop yields (Figure 4). Yield responses 
to DI were significantly lower in soils with coarse and medium textures (Figure 7). Irrigation water use efficiency was weakly significantly different among irrigation classes and water regimes but was significantly higher in the experiment conducted at Matera (Figure 10), coupled with semiarid climate conditions (Figure 11).

\section{Conclusions and Recommendations}

Under Mediterranean conditions, water management is a crucial factor for tomato crops, due to the limited availability of water resources during the growing season, when evapotranspiration is not balanced by the moderate amount of rainfall. Therefore, in this environment, the sustainable use of water resources is a priority. A proper application of DI can save huge amounts of water, particularly in semi-arid environments where water scarcity is an increasing concern and water costs are continuously rising.

Our results provide practical guidelines for irrigation water use in processing tomato cultivation that can be easily addressed by farmers to avoid over-irrigation and to adopt reduced irrigation rates during the less sensitive growth stages. Our recommendation is that further research should address the response of crop yield under variable irrigation regimes adopting RDI, and in relation either to coarse and medium soil textures and sub-humid climate conditions that are very frequent in Mediterranean Italy.

Alternative strategies to reduce irrigation water use can be recommended, namely sensor-based irrigation scheduling [41] or partial root-zone drying [35]. However, their implementation involves higher costs for farmers in terms of irrigation equipment and management compared to deficit or regulated deficit irrigation.

Supplementary Materials: The following are available online at http:/www.mdpi.com/2077-0472/9/4/79/s1, Table S1: Main details of field experiments.

Author Contributions: R.F. and C.D.B. made substantial contributions to the manuscript. R.F. performed data curation and writing - review and editing; C.D.B. performed writing-review and editing.

Funding: This research was funded by the Diverfarming project "Crop diversification and low-input farming across Europe: from practitioners' engagement and ecosystems services to increased revenues and value chain organisation", a European Union's Horizon 2020 Programme for Research and Innovation, under grant agreement no 728003 .

Conflicts of Interest: The authors declare no conflict of interest.

\section{References}

1. FAO (Food and Agriculture Organization of the United Nations). FAO Statistical Yearbook 2012. Available online: http://www.fao.org/docrep/015/i2490e/i2490e00.htm (accessed on 7 April 2019).

2. Du, Y.D.; Niu, W.Q.; Gu, X.B.; Zhang, Q.; Cui, B.J. Water- and nitrogen-saving potentials in tomato production: A meta-analysis. Agr. Water Manag. 2018, 210, 296-303. [CrossRef]

3. Molden, D. Water for Food, Water for Life: A Comprehensive Assessment of Water Management in Agriculture; Earthscan and Colombo, International Water Management Institute: London, UK, 2007; 688p.

4. FAO (Food and Agriculture Organization of the United Nations). AQUASTAT Main Database 2016. Available online: http://www.fao.org/nr/water/aquastat/data/query/index.html (accessed on 7 April 2019).

5. Yahyaoui, I.; Tadeo, F.; Vieira, M. Energy and water management for drip-irrigation of tomatoes in a semi-arid district. Agr. Water Manag. 2017, 183, 4-15. [CrossRef]

6. Costa, J.M.; Ortuno, M.F.; Chaves, M.M. Deficit irrigation as a strategy to save water: Physiology and potential application to horticulture. J. Integr. Plant Biol. 2007, 49, 1421-1434. [CrossRef]

7. Mushtaq, S.; Moghaddasi, M. Evaluating the potentials of deficit irrigation as an adaptive response to climate change and environmental demand. Environ. Sci. Policy 2011, 14, 1139-1150. [CrossRef]

8. Ali, M.H.; Hoque, M.R.; Hassan, A.A.; Khair, A. Effects of deficit irrigation on yield, water productivity, and economic returns of wheat. Agr. Water Manag. 2007, 92, 151-161. [CrossRef]

9. Vazifedoust, M.; Van Dam, J.C.; Feddes, R.A.; Feizi, M. Increasing water productivity of irrigated crops under limited water supply at field scale. Agr. Water Manag. 2008, 95, 89-102. [CrossRef] 
10. Rodriguez-Ortega, W.; Martinez, V.; Rivero, R.; Camara-Zapata, J.; Mestre, T.; Garcia-Sanchez, F. Use of a smart irrigation system to study the effects of irrigation management on the agronomic and physiological responses of tomato plants grown under different temperatures regimes. Agr. Water Manag. 2017, 183, 158-168. [CrossRef]

11. Zegbe-Domínguez, J.A.; Behboudian, M.H.; Lang, A.; Clothier, B.E. Deficit irrigation and partial rootzone drying maintain fruit dry mass and enhance fruit quality in 'Petopride' processing tomato (Lycopersicon esculentum, Mill.). Sci. Hortic. 2003, 98, 505-510. [CrossRef]

12. Patanè, C.; Tringali, S.; Sortino, O. Effects of deficit irrigation on biomass, yield, water productivity and fruit quality of processing tomato under semi-arid Mediterranean climate conditions. Sci. Hortic. 2011, 129, 590-596. [CrossRef]

13. Zhang, H.M.; Xiong, Y.W.; Huang, G.H.; Xu, X.; Huang, Q.Z. Effects of water stress on processing tomatoes yield, quality and water use efficiency with plastic mulched drip irrigation in sandy soil of the Hetao Irrigation District. Agric. Water Manag. 2017, 179, 205-214. [CrossRef]

14. Chen, J.L.; Kang, S.Z.; Du, T.S.; Guo, P.; Qiu, R.Q.; Chen, R.Q.; Gu, F. Modeling relations of tomato yield and fruit quality with water deficit at different growth stages under greenhouse condition. Agr. Water Manag. 2014, 146, 131-148. [CrossRef]

15. WPTC (World Processing Tomato Council). Available online: http://www.wptc.to/ (accessed on 22 March 2019).

16. ISTAT (Istituto Nazionale di Statistica). Available online: http://agri.istat.it/ (accessed on 22 March 2019).

17. Battilani, A. Processing tomato water and nutrient integrated crop management: State of art and future horizons. Acta Hortic. 2003, 613, 63-73. [CrossRef]

18. Rinaldi, M.M.; Thebaldi, M.S.; da Rocha, M.S.; Sandri, D.; Felisberto, A.B. Postharvest quality of the tomato irrigated by different irrigation systems and water qualities. IRRIGA 2013, 18, 59-72. [CrossRef]

19. Benincasa, P.; Guiducci, M.; Tei, F. The nitrogen use efficiency: Meaning and sources of variation - case studies on three vegetable crops in Central Italy. Hort. Technol. 2011, 21, 266-273. [CrossRef]

20. Fereres, E.; Soriano, M.A. Deficit irrigation for reducing agricultural water use. J. Exp. Bot. 2007, 58, 147-159. [CrossRef] [PubMed]

21. Giuliani, M.; Nardella, E.; Gagliardi, A.; Gatta, G. Deficit irrigation and partial root-zone drying techniques in processing tomato cultivated under Mediterranean climate conditions. Sustainability 2017, 9, 2197. [CrossRef]

22. Rinaldi, M.; Garofalo, P.; Vonella, A.V. Productivity and water use efficiency in processing tomato under deficit irrigation in Southern Italy. In XIII International Symposium on Processing Tomato, Sirmione, Italy. Acta Hort. 2015, 1081, 97-104. [CrossRef]

23. Ventrella, D.; Giglio, L.; Charfeddine, M.; Lopez, R.; Castellini, M.; Sollitto, D.; Castrignanò, A.; Fornaro, F. Climate change impact on crop rotations of winter durum wheat and tomato in southern Italy: Yield analysis and soil fertility. Ital. J. Agron. 2012, 7, 15. [CrossRef]

24. Ventrella, D.; Giglio, L.; Garofalo, P.; Dalla Marta, A. Regional assessment of green and blue water consumption for tomato cultivated in Southern Italy. J. Agr. Sci. 2018, 156, 689-701. [CrossRef]

25. Marouelli, W.A.; Silva, W.L.C. Water tension thresholds for processing tomatoes under drip irrigation in Central Brazil. Irrig. Sci. 2007, 25, 411-418. [CrossRef]

26. Patanè, C.; Cosentino, S.L. Effects of soil water deficit on yield and quality of processing tomato under a Mediterranean climate. Agr. Water Manag. 2010, 97, 131-138. [CrossRef]

27. Allen, R.G.; Pereira, L.S.; Raes, D.; Smith, M. Crop evapotranspiration. In Guidelines for Computing Crop Water Requirements; FAO: Rome, Italy, 1998; Irrigation and Drainage Paper Volume 56, p. 300.

28. Doorenbos, J.; Pruitt, W.O. Crop Water Requirements; FAO Irrigation and Drainage Paper 24; FAO: Rome, Italy, 1977; p. 144.

29. Cantore, V.; Lechkar, O.; Karabulut, E.; Sellami, M.H.; Albrizio, R.; Boari, F.; Stellacci, A.M.; Todorovic, M. Combined effect of deficit irrigation and strobilurin application on yield, fruit quality and water use efficiency of "cherry" tomato (Solanum lycopersicum L.). Agr. Water Manag. 2016, 167, 53-61. [CrossRef]

30. Giuliani, M.M.; Gatta, G.; Nardella, E.; Tarantino, E. Water saving strategies assessment on processing tomato cultivated in Mediterranean region. Ital. J. Agron. 2016, 11, 69-76. [CrossRef]

31. Lovelli, S.; Potenza, G.; Castronuovo, D.; Perniola, M.; Candido, V. Yield, quality and water use efficiency of processing tomatoes produced under different irrigation regimes in Mediterranean environment. Ital. J. Agron. 2017, 12, 17-24. [CrossRef] 
32. Leogrande, R.; Lopedota, O.; Montemurro, F.; Vitti, C.; Ventrella, D. Effects of irrigation regime and salinity on soil characteristics and yield of tomato. Ital. J. Agron. 2012, 7, 50-57. [CrossRef]

33. Candido, V.; Campanelli, G.; D'Addabbo, T.; Castronuovo, D.; Perniola, M.; Camele, I. Growth and yield promoting effect of artificial mycorrhization on field tomato at different irrigation regimes. Sci. Hortic. 2015, 187, 35-43. [CrossRef]

34. Colla, G.; Casa, R.; Lo Cascio, B.; Saccardo, F.; Temperini, O.; Leoni, C. Responses of processing tomato to water regime and fertilization in Central Italy. In Proceedings of the VI International Symposium on Processing Tomato and Workshop on Irrigation and Fertigation of Processing Tomato, Pamplona, Spain. Acta Hort. 1999, 487, 531-536. [CrossRef]

35. Casa, R.; Rouphael, Y. Effects of partial root-zone drying irrigation on yield, fruit quality, and water-use efficiency in processing tomato. J. Hortic. Sci. Biotech. 2014, 89, 389-396. [CrossRef]

36. Howell, T.A.; Steiner, J.E.; Schneider, A.D.; Evertt, S.R.; Tolk, J.A. Seasonal and maximum daily evapotranspiration of irrigated winter wheat, sorghum and corn: Southern high plains. Trans. Asae 1997, 40, 623-634. [CrossRef]

37. De Martonne, E. Une nouvelle fonction climatologique: l'indice d'aridite. Meteorologie 1926, 2, 449-458.

38. Soil Survey Staff. Keys to Soil Taxonomy, 12th ed.; USDA-Natural Resources Conservation Service: Washington, DC, USA, 2014; p. 360.

39. Zornoza, R.; Rosales, R.M.; Acosta, J.A.; de la Rosa, J.M.; Arcenegui, V.; Faz, Á.; Pérez-Pastor, A. Efficient irrigation management can contribute to reduce soil $\mathrm{CO}_{2}$ emissions in agriculture. Geoderma 2016, 263, 70-77. [CrossRef]

40. Cayuela, M.L.; Aguilera, E.; Sanz-Cobena, A.; Adams, D.C.; Abalos, D.; Barton, L.; Ryals, R.; Silver, W.L.; Alfaro, M.A.; Pappa, V.A.; et al. Direct nitrous oxide emissions in Mediterranean climate cropping systems: Emission factors based on a meta-analysis of available measurement data. Agr. Ecosyst. Environ. 2017, 238, 25-35. [CrossRef]

41. Zotarelli, L.; Dukes, M.D.; Scholberg, J.M.S.; Munoz-Carpena, R.; Icerman, J. Tomato nitrogen accumulation and fertilizer use efficiency on a sandy soil, as affected by nitrogen rate and irrigation scheduling. Agr. Water Manag. 2009, 96, 1247-1258. [CrossRef]

(C) 2019 by the authors. Licensee MDPI, Basel, Switzerland. This article is an open access article distributed under the terms and conditions of the Creative Commons Attribution (CC BY) license (http://creativecommons.org/licenses/by/4.0/). 